\title{
Efektivitas Bahan Ajar Terintegrasi PPK, Literasi Dan Learning and Innovation Skills (4C's) pada Mata Kuliah Kalkulus I
}

\author{
${ }^{1}$ Sunismi, ${ }^{2}$ Abdul Halim Fathani, ${ }^{3}$ Muhammad Baidawi \\ ${ }^{1,2}$ Pendidikan Matematika FKIP, Universitas Islam Malang \\ Jl. Mayjen Haryono No.193, Dinoyo, Kec. Lowokwaru, Kota Malang Indonesia \\ ${ }^{3}$ Pendidikan Matematika FKIP, Universitas Wisnuwardhana Malang \\ Jl. Terusan Danau Sentani No.99, Madyopuro, Kec. Kedungkandang, Kota \\ Malang, Jawa Timur, Indonesia \\ Email: ${ }^{1}$ sunismiunisma@yahoo.com, ${ }^{2}$ fathani@unisma.ac.id, \\ 3baidawi_muhammad@ymail.com
}

\section{Tersedia Online di \\ http://www.jurnal.unublitar.ac.id/ index.php/briliant}

\begin{tabular}{l}
\hline Sejarah Artikel \\
\hline Diterima pada November 2020 \\
Disetuji pada Maret 2021 \\
Dipublikasikan pada Mei 2021 \\
Hal. 329-342 \\
\hline Kata Kunci: \\
\hline Bahan ajar; PPK; Literasi; \\
Learning and Innovation Skills \\
(4C's) \\
\hline DOI: \\
\hline http://dx.doi.org/10.28926/briliant \\
.v3i4.581
\end{tabular}

Abstrak: Penelitian ini bertujuan untuk menguji efektivitas bahan ajar terintegrasi PPK, literasi dan, learning and innovation skills (4C's) pada mata kuliah kalkulus I. Pendekatan penelitian menggunakan quasi eksperimental research. Dengan desain nonequivalent control group design. Penelitian ini dilaksanakan di Prodi Pendidikan Matematika FKIP Unisma tahun akademik 2019/2020. Sampel ditentukan dengan teknik convenience sampling terpilih 2 kelas berjumlah 57 mahasiswa. Perlakuan kelompok eksperimen dalam pembelajaran menggunakan bahan ajar kalkulus I terintegrasi PPK, literasi dan, learning and innovation skills (4C's), sedangkan kelompok kontrol menggunakan hand out kalkulus I dari dosen. Instrumen yang digunakan adalah soal tes berpikir tingkat tinggi (berpikir kritis dan kreatif). Analisis data dilakukan dengan uji independent sample $t$ test dua pihak untuk menguji perbedaan rerata dan uji independent sample t test satu pihak untuk uji efektivitas bahan ajar. Hasil penelitian dengan uji $\mathrm{t}$ dua pihak diperoleh terdapat perbedaan kemampuan berpikir tingkat tinggi (berpikir kritis dan berpikir kreatif) mahasiswa yang dalam pembelajaran menggunakan bahan ajar terintegrasi PPK, literasi dan, learning and innovation skills (4C's) dibanding dengan yang menggunakan hand out dosen pada mata kuliah kalkulus I. Demikian juga berdasarkan uji independent sample t test satu pihak dihasilkan bahwa bahan ajar terintegrasi PPK, literasi dan, learning and innovation skills (4C's) lebih efektif dibanding hand out dosen pada mata kuliah kalkulus I untuk meningkatkan kemampuan berpikir tingkat tinggi mahasiswa.

\section{PENDAHULUAN}

21st century skills sangat dibutuhkan para lulusan agar dapat berkompetisi pada era globalisasi. Pentingnya menguasai 21 st century skills di era globalisasi, karena sangat diperlukan oleh para lulusan agar dapat berkompetisi dengan maksimal. The Partnership for 21st Century Skills (P21, 2008), merupakan suatu organisasi mengembangkan keterampilan-keterampilan yang dibutuhkan peserta didik agar berhasil di lingkungan abad 21, ada 3 keterampilan yang harus diajarkan pada peserta didik termasuk mahasiswa yaitu (1) life and career skills, (2) learning and innovation skills, dan (3) information, media and technology skills. Dimana 
Learning and innovation skills merupakan salah satu keterampilan penting dan harus dikuasai peserta didik pada jenjang perguruan tinggi. Dimana Learning and innovation skills terdiri dari 4 keterampilan disebut 4C's, meliputi Creativity and Innovation, Critival Thinking and Problem Solving, Communication, and Collaboration (P21, 2008)(Trilling \& Fadel, 2009]. Dimana Critical Thinking and Problem Solving Skills,merupakan kemampuan berfikir kritis, lateral, dan sistemik, terutama dalam konteks pemecahan masalah; Communication and Collaboration Skills, kemampuan berkomunikasi dan berkolaborasi secara efektif dengan berbagai pihak; dan Creativity and Innovation Skills, kemampuan mengembangkan kreativitas untuk menghasilkan berbagai terobosan yang inovatif. Sedangkan menurut Griffin \& Care (2015) menggolongkan keterampilan dan sikap abad 21 sebagai ways to thinking (knowledge, critical and creative thinking), ways to learning (literacy and soft skills), dan ways to learning with other. Oleh karena itu agar learning and innovation skills (4C's) dapat dicapai maksimal, maka harus diintegrasikan dalam pembelajaran, baik dalam proses pembelajaran maupun diintegrasikan dalam bahan ajar. Dengan harapan kemampuan yang harus dicapai peserta didik tidak hanya pada pencapaian kemampuan kognitif saja, namun juga pada pencapaian kemampuan berpikir kritis, kreatif, kolaboratif, dan komunikatif.

Menurut Setyaningsih (2018), Perguruan Tinggi (PT), dimana LPTK merupakan lembaga yang diharapkan dapat menyiapkan calon guru yang dapat menghadapi tantangan perkembangan ilmu pengetahuan dan teknologi pada abad 21. Hal ini sesuai dengan UUGD Pasal 1 Ayat (14), bahwa LPTK merupakan lembaga perguruan tinggi yang diberi tugas pemerintah untuk menyelenggarakan program pengadaan guru pada pendidikan formal, pendidikan dasar, dan pendidikan menengah untuk mengembangkan ilmu kependidikan dan ilmu pengetahuan yang lain. Berdasarkan UUGD tersebut guru (calon guru) merupakan ujung tombak pelaksana pembelajaran di lapangan. Guru tidak dapat menghindar dari konsekuensi perubahan paradigma pembelajaran abad 21. Oleh karena itu LPTK harus dapat menyelenggarakan pembelajaran yang inovatif sehingga kelak calon guru memperoleh bekal untuk menghadapi tantangan guru abad 21. Melihat perkembangan IPTEKS yang demikian pesat, tidak bisa dipungkiri bahwa LPTK memiliki andil yang sangat besar dalam menghasilkan calon guru yang mahir teknologi.

LPTK sebagai lembaga pencetak calon guru harus dapat membekali lulusan berbagai kemampuan yang dibutuhkan pada abad 21 dan kemampuan untuk menghadapi tantangan globalisasi dan inovasi teknologi. LPTK harus: 1) dapat menerapkan bahan pmembelajaran dengan critical thinking, creative thinking, collaboration, dan communication; 2) dapat memfasilitasi peserta didik menguasai new literacy (literasi data dan literasi teknologi), maka proses pembelajaran memanfaatkan alat dan sumber belajar digital; 3) dapat melaksanakan pembelajaran terintegrasi dengan teknologi digital melalui pendekatan technological, pedagogical, and content knowledge. Dimana learning and innovation skills (4C's) merupakan keterampilan yang sangat dibutuhkan oleh lulusan LPTK. Hal ini sesuai Nudyansyah (2016), bahwa guru harus dapat merancang pembelajaran dengan metode mengajar inovatif, teori dan penalaran. Demikian juga AITSL (2011), menyatakan bahwa guru harus mampu membimbing anak-anak generasi $\mathrm{Z}$, maka

330 BRILIANT: Jurnal Riset dan Konseptual Volume 6 Nomor 2, Mei 2021 
harus memiliki tiga kompetensi, yaitu (1) professional knowledge (2) professional practice, (3) professional engagement.

Demikian juga sebagai calon guru matematika, sangat perlu dibekali learning and innovation skills (4C's) karena sangat relevan dengan karakterik matematika. Dimana karakterik matematika, antara lain: a) dapat melatih cara berfikir dan bernalar dalam menarik kesimpulan, b) dapat mengembangkan aktivitas kreatif yang melibatkan imajinasi, intuisi dan penemuan, c) dapat mengembangkan kemampuan memecahkan masalah, dan d) dapat mengembangkan kemampuan untuk menyampaikan informasi atau mengkomunikasikan gagasan pada yang lain (Depdiknas, 2003). Termasuk pada lulusan calon guru matematika di LPTK Program studi pendidikan matematika Universitas Islam Malang, harus disiapkan agar keterampilan abad 21 dapat dicapai secara maksimal. Dengan demikian perkuliahan dilakukan dengan mengintegrasikan learning and innovation skills (4C's) sebagai tujuan perkuliahan. Termasuk pada tujuan perkuliahan kalkulus I, mata kuliah kalkulus I merupakan mata kuliah wajib ditempuh mahasiswa pada semester I. Agar tujuan perkuliahan memuat 4C's dapat tercapai dengan baik, maka 4C's harus diintegrasikan pada bahan ajar tersebut. Dimana bahan ajar merupakan suatu materi perkuliahan disusun secara sistematis yang digunakan dosen dan mahasiswa dalam pembelajaran untuk mencapai tujuan yang diharapkan.

Bahan ajar kalkulus I digunakan sebagai penunjang bagi mahasiswa agar dapat memahami materi kalkulus I ini dengan mudah. Bahan ajar ini disusun dengan mengintegrasikan PPK, Literasi dan 4C's, dengan tujuan agar mahasiswa terampil dalam berpikir tingkat tinggi (berpikir kritis dan berpikir kreatif). Sehingga dapat menghadapi perkembangan ilmu dan teknologi yang semakin pesat. Bahan ajar kalkulus I diintegrasikan PPK (Penguatan Pendidikan Karakter), berupa pesan moral yang memuat nilai-nilai karakter, sehingga mahasiswa dapat menerapkan nilai-nilai karakter dalam kehidupan sehari-hari dalam kehidupan bermasyarakat. Digital Literacy, diberikan link buku-buku kalkulus I sebagai referensi lain, dan link video-video materi kalkulus I yang dipelajari, agar dapat memperluas wawasan pengetahuan mahasiswa. Demikian juga dengan 4C's, meliputi: Critical Thinking, merupakan keterampilan fundamental dalam memecahkan masalah. Keterampilan ini penting dimiliki oleh mahasiswa dalam menemukan sumber masalah dan menemukan solusi yang tepat. Oleh karena itu dosen dapat merancang dan mengembangkan pembelajaran yang lebih terfokus pada pemberdayaan keterampilan ini (Zubaidah, 2019). Creative Thinking, merupakan keterampilan menggunakan pendekatan yang baru untuk menyelesaikan suatu permasalahan, inovasi, dan penemuan. Keterampilan berpikir jratif merupakan suatu ide baru dan asli, baik secara pribadi atau secara budaya (Abdullah dan Osman, 2010). Communication skill, merupakan keterampilan dalam memunculkan pemikiran, gagasan, pengetahuan, ataupun informasi baru secara tertulis maupun lisan (NEA, 2012). Collaboration skill, merupakan keterampilan bekerja sama secara efektif dan menunjukkan rasa hormat, melatih kelancaran dan kemauan dalam membuat keputusan untuk mencapai tujuan bersama (NEA, 2012). Keterampilanketerampilan tersebut merupakan keterampilan yang harus dicapai mahasiswa dalam belajar mata kuliah kalkulus I, bukan sekadar transfer materi. Karena dengan 
pentingnya penguasaan 4C's sebagai sarana meraih kesuksesan di Abad 21, yang merupakan abad dengan perkembangan sangat cepat dan dinamis. Penguasaan keterampilan abad 21 sangat penting, 4C's adalah jenis softskill lebih bermanfaat daripada hanya sekedar pengusaan hardskill.

Berdasarkan uraian di atas, menunjukkan bahwa betapa pentingnya learning and innovation skills (4C's) bagi calon guru, karena sangat diperlukan untuk bekal kelak menjadi guru profesional. Oleh karena itu tujuan dari penelitian ini adalah untuk mengetahui efektivitas penerapan bahan ajar yang bermuatan Learning and innovation skills pada kemampuan berpikir tingkat tinggi (berpikir kritis dan berpikir kreatif). Oleh karena itu, peneliti bermaksud untuk mengetahui hasil uji efektivitas penerapan bahan ajar matakuliah kalkulus I bermuatan learning and innovation skills (4C's) pada kemampuan berpikir tingkat tinggi mahasiswa calon guru matakuliah kalkulus I.

\section{METODE}

Metode dalam penelitian ini menggunakan penelitian kuantitatif dengan jenis penelitian quasi experimental design. Sugiyono (2010) menyatakan bahwa ciri quasi experimental design kelompok kontrol tidak dapat mengontrol secar penuh variabel-variabel dari luar yang mempengaruhi kelompok eksperimen. Oleh karena itu quasi experimental design merupakan jenis penelitian yang memiliki kelompok kontrol dan kelompok eksperimen tidak dipilih secara random.

Desain quasi experimental menggunakan model nonequivalent control group design. Sebelum diberi perlakuan, kelompok eksperimen dan kelompok kontrol diberi pretes, untuk mengetahui keadaan kedua kelompok tersebut sebelum diberi perlakuan. Kemudian setelah diberikan perlakuan, kelompok eksperimen dan kelompok kontrol diberikan postes, untuk mengukur keadaan kelompok setelah diberi perlakuan. Pada penelitian ini kelompok eksperimen, diberi perlakuan dalam pembelajaran dengan menerapkan bahan ajar kalkulus I terintegrasi PPK, Literasi, dan learning and innovation skills (4C's). Sedangkan kelompok kontrol dengan menerapkan buku kalkulus I yang biasa digunakan, yaitu hand out dari dosen.

Populasi dalam penelitian ini adalah seluruh mahasiswa Prodi Pendidikan Matematika FKIP Unisma semester I sebanyak 3 kelas tahun akademik 2019/2020 yang menempuh matakuliah kalkulus I. Sampel diambil dengan menggunakan teknik convenience sampling merupakan pengambilan sampel didasarkan pada elemen yang tersedia. Oleh karena itu terpilih sampel 2 kelas, yaitu semester IA berjumlah 28 sebagai kelas eksperimen dan semester IB berjumlah 29 sebagai kelas kontrol, sehingga total sampel berjumlah 57 mahasiswa.

Teknik pengumpulan data menggunakan teknik tes untuk memperoleh data pretes dan data postes pada kelompok eksperimen dan kelompok kontrol. Sedangkan instrumen dalam penelitian ini berupa soal tes (pretes dan postes) untuk mengukur kemampuan berpikir tingkat tinggi mahasiswa (berpikir kritis dan kreatif) mata kuliah kalkulus I. Bentuk soal tes (pretes dan postes) essay yang terdiri dari 4 soal. Instrumen yang digunakan dilakukan uji validitas instrumen. Sugiyono (2010) menjelaskan bahwa pengujian validitas instrumen salah satunya dapat dilakukan dengan pengujian validitas konstrak. Pengujian validitas konstrak yaitu uji instrumen dengan menggunakan ahli atau experts judgment. Indikator 
kemampuan berpikir tingkat tinggi, terdiri dari kemampuan berpikir kritis mengacu pada pendapat Anderson and Krathwohl (2001), DeWealsche, 2015, yaitu Analysing (differentiating, organizing, attributing), Evaluating (checking, criticizing, judging), dan Creating (formulating, planning, producing). Demikian juga indikator kemampuan berpikir kreatif, seperti yang dinyatakan oleh McGregor (2007) states that, creative thinking is the thinking that led to the idea of new, new approaches, or a new way of understanding things.

Teknik Analisis data dalam penelitian ini dilakukan 2 pengujian analisis data yaitu uji analisis data pretes dan uji analisis data postes. Dengan terlebih dahulu melakukan uji prasyarat analisis. Uji prasyarat analisis yaitu pengujian normalitas dan homogenitas, selanjutnya dilakukan uji analisis data pretes dan uji hipotesis data postes. Uji normalitas digunakan untuk memeriksa apakah data yang diperoleh dari masing-masing variabel distribusi normal atau tidak. Perhitungan uji normalitas pada penelitian ini menggunakan software SPSS 23.0 for Windows melalui The Kolmogorov Smirnov Normality Test. Sedangkan uji homogenitas varian, menurut Santoso (2014) bahwa uji homogenitas untuk mengetahui apakah kedua kelompok mempunyai varians yang sama atau tidak. Pengujian uji homogenitas menggunakan uji $F$ yang dihitung menggunakan software SPSS 23.0 for Windows melalui uji One-Way ANOVA melalui uji Levene's. Uji hipotesis pada penelitian ini menggunakan uji independent sample t test dua pihak untuk hipotesis rata-rata dua kelompok dengan menggunakan bantuan software SPSS 23.0 for Windows. Sedangkan untuk mengetahui rata-rata dua kelompok eksperimen dan kelompok kontrol mana yang lebih baik, digunakan uji independent sample t test satu pihak, dalam penelitian ini menggunakan perhitungan manual.

\section{HASIL DAN PEMBAHASAN}

Sebelum dilakukan pengujian analisis data pretes dan postes, maka terlebih dahulu dilakukan uji validasi instrumen. Uji validasi instrumen dilakukan dengan menggunakan ahli atau experts judgment. Hasil penilaian ahli dengan cara menyesuaikan antara soal tes berpikir tingkat tinggi dengan indikatornya, dan diperoleh hasil kesesuaian antara indikator dan soal tes sebesar 88,5\%, sehingga soat tes kemampuan berpikir tingkat tinggi dikatakan valid dan dapat digunakan untuk pengambilan data selanjutnya.

Pelaksanaan uji efektifitas bahan ajar matakuliah kalkulus I teringrasi PPK, literasi, dan bermuatan learning and innovation skills (4C's) pada kemampuan berpikir tingkat tinggi mahasiswa calon guru. Sampel dalam penelitian ini adalah mahasiswa semester I tahun akademik 2019/2020 program studi pendidikan matematika FKIP Unisma yang menempuh mata kuliah kalkulus I, yang terdiri dari dua kelas, yaitu kelas IA berjumlah 28 sebagai kelas eksperimen dan Kelas IB berjumlah 29 sebagai kelas kontrol, sehingga sampel berjumlah 57 mahasiswa.

\section{Analisis Data Pretes}

Pada analisis data pretes dilakukan uji kesamaan rata-rata. Uji kesamaan dua rata-rata ini bertujuan untuk mengetahui apakah kelompok eksperimen dan kelompok kontrol mempunyai rata-rata yang tidak berbeda pada tahap awal ini. Sebelum dilakukan uji kesamaan rata-rata dengan menggunakan Independent 
Sample T-Test perlu dilakukan uji prasyaratnya terlebih dahulu, yaitu uji normalitas dan uji homogenitas.

\section{Uji Normalitas}

Uji normalitas untuk mengetahui data pretes berasal dari populasi yang berdistribusi normal atau tidak. Uji normalitas menggunakan uji Lilliefors (Kolmogorov-Smirnov) normality test dengan menggunakan program SPSS 23.0 for Windows dengan taraf signifikansi 0,05. Tampilan output dapat dilihat pada Tabel 1 berikut ini.

Tabel 1 Uji Normalitas Data Pretes

\begin{tabular}{lcccc}
\hline \multirow{2}{*}{ Kelas } & \multicolumn{4}{c}{ The Kolmogorov Smirnov Normality Test } \\
\cline { 2 - 5 } & Statistic & $\mathrm{df}$ & \multicolumn{2}{c}{ Sig. } \\
\hline \multirow{2}{*}{ Pretes } & Eksperimen &, 110 & 28 &, $200^{*}$ \\
\cline { 2 - 5 } & Kontrol &, 152 & 28 &, 096 \\
\hline
\end{tabular}

Berdasarkan Tabel 1, hasil output SPSS 23.0 for Windows bahwa uji normalitas data pretes untuk kelompok eksperimen diperoleh nilai sig $=0,200>$ 0,05, demikian juga pada kelompok kontrol diperoleh nilai sig $=0,096>0,05$. Maka data pretes kelompok eksperimen dan kelompok kontrol memenuhi distribusi normal.

\section{Uji Homogenitas}

Uji homogenitas menggunakan uji One-Way ANOVA melalui uji Levene's dengan bantuan program SPSS 23.0 for Windows dengan taraf signifikansi 0,05. Setelah dilakukan pengolahan data, diperoleh hasil output seperti terlihat Tabel 2 berikut ini.

Tabel 2: Uji Homogenitas Data Pretes Kelompok Sampel di Unisma Malang

\begin{tabular}{|c|c|c|c|}
\hline \multirow{2}{*}{$\begin{array}{c}\text { Data pretes, kelas } \\
\text { Eksperimen dan } \\
\text { Kontrol }\end{array}$} & \multirow{2}{*}{$\begin{array}{l}\text { The Levene's Test } \\
\text { for Equality of } \\
\text { Variances }\end{array}$} & \multirow{2}{*}{$\begin{array}{c}\text { Sig. } \\
817\end{array}$} & Keterangan \\
\hline & & & $H_{0}$ diterima \\
\hline
\end{tabular}

Berdasarkan Tabel 2, hasil output uji homogenitas Kelas eksperimen dan kelas kontrol memperoleh nilai sig 0,780 >0,05, maka kedua kelas memiliki varians yang sama atau homogen.

\section{Uji Kesamaan Rata-rata}

Setelah memenuhi uji prasyarat, maka dilanjutkan uji kesamaan rata-rata dengan menggunakan uji t dua pihak. Dengan bantuan program SPSS 23.0 for Windows menggunakan Independent Sample T-Test dengan taraf signifikansi 0,05. Setelah dilakukan analisis data pretes, sehingga diperoleh hasil uji t dapat dilihat pada Tabel 3.

Tabel 3 Uji-t Data Pretes

\begin{tabular}{lcc}
\multirow{2}{*}{ Equal variances asumed } & Sig. (2-tailed) & Keterangan \\
\cline { 2 - 3 } &, 308 & $H_{0}$ diterima \\
\hline
\end{tabular}

$\overline{\text { Berdasarkan Tabel 3, hasil output uji Independent Sample T-Test diperoleh }}$ nilai sig.2-tailed $=0,308>0,05$, maka $H_{0}$ diterima. Kesimpulan bahwa kelas eksperimen (menggunakan bahan ajar terintegrasi PPK, Literasi, 4C's) dan kelompok kontrol (menggunakan hand out dosen) tidak berbeda secara signifikan.

334 BRILIANT: Jurnal Riset dan Konseptual Volume 6 Nomor 2, Mei 2021 


\section{Analisis Data Postes}

Setelah diketahui bahwa kelas eksperimen dan kontrol memenuhi uji kesamaan rata-rata, maka selanjutnya dilakukan uji hipotesis. Uji hipotesis untuk mengetahui mengetahui kedudukan kelas eksperimen dan kelas kontrol terhadap kemampuan berpikir tingkat tinggi (kemampuan berpikir kritis dan kreatif), juga menggunakan Independent Sample T-Test dua pihak. Dengan terlebih dahulu melakukan uji prasyarat, yaitu uji normalitas dan uji homogenitas.

\section{Nilai Rata-rata dan Simpangan Baku}

Data postes untuk mengetahui kemampuan berpikir tingkat tinggi mahasiswa pada kelompok eksperimen dan kelompok kontrol berbeda atau sama. Nilai postes memiliki rentang 0-100. Dari hasil pengolahan data postes untuk masing-masing kelas, yaitu kelompok eksperimen dan kelompok kontrol, diperoleh nilai rerata dan simpangan baku seperti pada Tabel 4 berikut ini.

Tabel 4 Rerata dan Simpangan Baku dari Data Postes

\begin{tabular}{l|c|r|c|r|r}
\hline & Kelas & \multicolumn{1}{c|}{ N } & Mean & Std. Deviation & Std. Error Mean \\
\hline \multirow{2}{*}{ Postes } & Eksperimen & 28 & 72,8929 & 10,52454 & 1,98895 \\
\cline { 2 - 6 } & Kontrol & 29 & 66,0690 & 10,52185 & 1,95386 \\
\hline
\end{tabular}

\section{Uji Normalitas}

Uji normalitas terhadap dua kelompok tersebut dilakukan dengan uji Lilliefors (Kolmogorov-Smirnov) normality test dengan menggunakan program SPSS 23.0 for Windows dengan taraf signifikansi 0,05. Setelah dilakukan pengolahan data, tampilan output dapat dilihat pada Tabel 5 berikut ini.

Tabel 5 Uji Normalitas Data Postes

\begin{tabular}{l|c|r|r|r}
\hline \multirow{2}{*}{} & \multirow{2}{*}{$\begin{array}{c}\text { Model } \\
\text { Pembelajaran }\end{array}$} & \multicolumn{3}{|c}{ The Kolmogorov Smirnov Normality Test } \\
\cline { 3 - 5 } & Statistic & df & \multicolumn{1}{c}{ Sig. } \\
\hline Postes & $\mathrm{CL}$ &, 109 & 28 &, $200^{*}$ \\
\cline { 2 - 5 } & $\mathrm{K}$ &, 152 & 28 &, 096 \\
\hline
\end{tabular}

Berdasarkan Tabel 5, hasil output uji normalitas dengan menggunakan uji Lilliefors (Kolmogorov-Smirnov) normality test untuk data postes diperoleh nilai sig. $=0,109$ pada kelompok eksperimen dan 0,152 kelompok kontrol lebih besar dari 0,05 , maka dapat disimpulkan bahwa data potes kelompok eksperimen dan kelompok kontrol berdistribusi normal.

\section{Uji Homogenitas}

Uji homogenitas menggunakan statistik uji Levene's dengan bantuan program SPSS 23.0 for Windows dengan taraf signifikansi 0,05. Hal ini dilakukan untuk melihat apakah data berasal dari variansi yang sama atau tidak. Setelah dilakukan pengolahan data, tampilan output dapat dilihat pada Tabel 6 berikut ini.

Tabel 6 Uji Homogenitas Data Postes

\begin{tabular}{|c|c|c|c|}
\hline \multirow{2}{*}{$\begin{array}{c}\text { Data pretes } \\
\text { Eksperimen dan } \\
\text { Kontrol } \\
\end{array}$} & \multirow{2}{*}{$\begin{array}{c}\text { The Levene's Test } \\
\text { for Equality of } \\
\text { Variances }\end{array}$} & Sig. & Keterangan \\
\hline & & ,780 & $H_{0}$ diterima \\
\hline
\end{tabular}


Berdasarkan Tabel 6, hasil output uji Levene's untuk data postes, diperoleh nilai sig. $=0,780$, lebih besar dari 0,05 , sehingga $\mathrm{H}_{0}$ diterima, maka dapat disimpulkan bahwa tidak terdapat perbedaan varians antara antara kelompok eksperimen dan kelompok kontrol atau homogen.

\section{Uji Hipotesis Dua Pihak}

Selanjutnya dilakukan uji hipotesis dengan menggunakan uji t dua pihak melalui program SPSS 23.0 for Windows menggunakan Independent Sample T-Test dengan taraf signifikansi 0,05 . Hipotesis dalam penelitian ini sebagai berikut.

$H_{0}: \mu_{1}=\mu_{2}$ : Tidak terdapat perbedaan kemampuan berpikir tingkat tinggi kelompok eksperimen dan kelompok kontrol.

$H_{a}: \mu_{1} \neq \mu_{2}$ : Terdapat perbedaan kemampuan berpikir tingkat tinggi kelompok eksperimen dan kelompok kontrol.

Hasil analisis data postes dapat dilihat pada Tabel 7 berikut ini.

Tabel 7 Uji-t Data Postes

\begin{tabular}{cccc}
\hline \multirow{2}{*}{$\begin{array}{c}\text { Equal variances } \\
\text { asumed }\end{array}$} & Sig. (2-tailed) & $\begin{array}{c}\text { Mean } \\
\text { Difference }\end{array}$ & Keterangan \\
\cline { 2 - 4 } &, 018 & 6,82389 & $H_{0}$ ditolak \\
\hline
\end{tabular}

Berdasarkan Tabel 7, hasil output Independent Sample T-Test untuk data postes diperoleh nilai sig.2-tailed $=0,018$ lebih kecil dari 0,05, maka $H_{0}$ diolak. Ini menunjukkan bahwa kemampuan berpikir tingkat tinggi mahasiswa antara kelas eksperimen (menggunakan bahan ajar terintegrasi PPK, Literasi, 4C's) dan kelompok kontrol (menggunakan hand out dosen) berbeda secara signifikan. Dengan perbedaan reratanya sebesar 6,82 .

\section{Uji Hipotesis Satu Pihak}

Selanjutnya dilakukan uji hipotesis untuk mengetahui mana yang lebih efektif penggunaan bahan ajar kalkulus I teringrasi dengan PPK, literasi, dan 4C's atau hand out kalkulus I dari dosen, maka dilakukan uji t satu pihak yang dihitung secara manual dengan taraf signifikansi 0,05. Hipotesis dalam penelitian ini sebagai berikut.

$H_{0}: \mu_{1} \leq \mu_{2}$ : Kemampuan berpikir tingkat tinggi kelompok eksperimen tidak lebih baik dari kelompok kontrol.

$H_{a}: \mu_{1}>\mu_{2}:$ Kemampuan berpikir tingkat tinggi kelompok eksperimen lebih baik dari kelompok kontrol.

Hasil analisis uji hipotesis digunakan uji t satu pihak dengan hitungan manual, diperoleh nilai $t_{\text {hitung }}=25,7557$. Berlandaskan uji hipotesis yang diperoleh dengan membandingkan antara $t_{\text {hitung }}$ dan $t_{\text {Tabel }}$ diperoleh $t_{\text {hitung }}>t_{\text {Tabel }}$ atau $25,7557>1,672$, dengan $d k=55$. Dengan demikian, $H_{\mathrm{o}}$ ditolak dan $H_{a}$ diterima sehingga kemampuan berpikir tingkat tinggi kelas eksperimen dengan bahan ajar terintegrasi PPK, literasi, dan 4C's lebih baik daripada kelas konvensional.

Berdasarkan hasil penelitian menunjukkan bahwa kemampuan berpikir tingkat tinggi mahasiswa antara kelas eksperimen (menggunakan bahan ajar kalkulus I terintegrasi PPK, Literasi, 4C's) dan kelompok kontrol (menggunakan hand out kalkulus I dari dosen) berbeda secara signifikan. Demikian juga 
berdasarkan uji independent sample t test satu pihak dihasilkan bahwa bahan ajar terintegrasi PPK, literasi dan, learning and innovation skills (4C's) lebih efektif dibanding hand out dosen pada mata kuliah kalkulus I untuk meningkatkan kemampuan berpikir tingkat tinggi mahasiswa.

Hal ini dikarenakan mahasiswa yang menggunakan bahan ajar kalkulus I terintegrasi PPK, Literasi, 4C's lebih terbimbing dan tertantang untuk mengembangkan kemampuan berpikirnya secara komprehensif dibanding dibanding bila mahasiswa menggunakan hand out dosen pada mata kuliah kalkulus I. Bila mahasiswa dibiasakan dihadapkan dengan masalah-masalah dan harus diselesaikan, maka dapat merangsang kemampuan berpikir tingkat tinggi. Hal ini sejalan dengan pernyataan Setiawati (2018), bahwa kemampuan berpikir tingkat tinggi merupakan kemampuan kompleks yang mencakup kemampuan memecahkan masalah (problem solving), keterampilan berpikir kritis (critical thinking), berpikir kreatif (creative thinking), kemampuan berargumen (reasoning), dan kemampuan mengambil keputusan (decision making). Kreativitas menyelesaikan masalah dalam berpikir tingkat tinggi, meliputi: (1) kemampuan menyelesaikan permasalahan tidak rutin atau tidak seperti biasanya, (2) kemampuan mengevaluasi strategi untuk menyelesaikan masalah, (3) menemukan model atau cara menyelesaikan permasalahan baru yang berbeda dengan cara-cara sebelumnya (Setiawati, et al., 2018). Hal ini juga diperkuat dengan tujuan pembelajaran matematika yaitu melatih dan menumbuhkan cara berfikir secara sistematis, logis, kritis, kreatif, dan konsisten, serta mengembangkan sifat gigih dan percaya diri dalam memecahkan masalah (Prihandoko, 2006).

Kemampuan berpikir tingkat tinggi memuat karakteristik antara lain kemampuan memecahkan masalah (problem solving), keterampilan berpikir kritis (critical thinking), dan berpikir kreatif (creative thinking). Oleh karena itu agar mahasiswa dapat mengembangkan kemampuan berpikir tingkat tinggi, maka harus dilatihkan atau dibiasakan menyelesaikan masalah-masalah berpikir tingkat tinggi yang merupakan proses berpikir yang melibatkan aktivitas mental yang tinggi, antara lain berpikir reflektif dan kreatif. Berpikir tingkat tinggi mendorong mahasiswa untuk menerapkan pengetahuan sebelumnya dan informasi baru untuk mengelola informasi tersebut dalam situasi baru. Oleh sebab itu model pembelajaran harus disesuaikan dengan aktivitas mahasiswa. Kemampuan berpikir tingkat tinggi sangat dituntut untuk dimiliki oleh mahasiswa agar dapat bersaing di era modern, dimana semua bidang sudah berbasis data, digital dan teknologi. Kreativitas untuk mencipta perlu diajarkan dan dilatihkan. Kemampuan mencipta merupakan salah satu indikator dari kemampuan berpikir tingkat tinggi, selain menganalisis, dan mengevaluasi. Agar mahasiswa berpikir kritis, maka harus diajari cara menganalisis dan mengevaluasi. Kemampuan-kemampuan yang harus diberikan kepada mahasiswa di era kecerdasan adalah kemampuan 4C's (Critical thinking, Collaboration, Communication, Creativity).

Berdasarkan hasil penelitian ini menunjukkan bahwa untuk melatihkan kemampuan berpikir tingkat tinggi pada mahasiswa, salah satu caranya dengan mengintegrasikan PPK, literasi, dan 4C's dalam bahan ajar. Hal ini dimaksudkan agar mahasiswa tertantang untuk menyelesaikan permasalahan yang terkait dengan kemampuan berpikir tingkat tinggi. Hal ini sesuai dengan pernyataan Limbach dan 
Waugh (2009) bahwa pengembangan keterampilan berpikir tingkat tinggi dapat diimplementasikan dalam setiap pembelajaran untuk menciptakan lingkungan belajar yang lebih aktif dan untuk mengarahkan mahasiswa menuju pemikiran pada tingkat yang lebih tinggi. Keterampilan berpikir tingkat tinggi dapat diterapkan pada berbagai disiplin ilmu salah satunya dalam pembelajaran matematika. Keunggulan keterampilan berpikir tingkat tinggi dapat menunjang prestasi akademik mahasiswa (Conklin \& Manfro, 2012). Ciri utama keterampilan berpikir tingkat tinggi adalah kemampuan berpikir kriitis dan berpikir kreatif (Collin, 2014).

Dalam penelitian ini tujuan bahan ajar kalkulus I diintegrasikan dengan PPK, Literasi dan 4C's, salah satunya untuk membekali mahasiswa calon guru lebih siap dalam menghadapi perkembangan ilmu dan teknologi pada abad 21. Dimana PPK (Penguatan Pendidikan Karakter), disampaikan berupa pesan moral yang memuat nilai-nilai karakter, untuk memperkuat karakter mahasiswa seperti: kejujuran, ketelitian, kemandirian dan kerjasama. Sehingga mahasiswa dapat menerapkan dalam kehidupan sehari-hari dan kehidupan bermasyarakat. Hal ini sesuai dengan (Perpres) No 87 Tahun 2017, bahwa Penguatan Pendidikan Karakter bertujuan untuk memperkuat karakter mahasiswa melalui harmonisasi kejujuran (olah hati), kecerdasan (olah pikir), ketangguhan (olah raga), dan kepedulian (olah rasa dan karsa) dengan melibatkan dan melakukan kerja sama antara sekolah/kampus, keluarga, dan masyarakat. Sedangkan Digital Literacy, dalam bahan ajar ini diberikan berupa link buku-buku kalkulus I sebagai referensi lain, dan link video-video yang terkait dengan materi yang dipelajari, agar dapat memperluas wawasan pengetahuan mahasiswa. Hal tersebut sesuai dengan pendapat kemendikbud (2016) literasi adalah kemampuan mengakses, memahami, dan menggunakan sesuatu secara cerdas melalui berbagai aktivitas, antara lain: membaca, melihat, menyimak, menulis, dan/atau berbicara.

Bahan ajar kalklus I diintegrasikan dengan 4C's, agar mahasiswa terbiasa berpikir yang sesuai dengan keterampilan abad 21. Hal ini diperkuat Collins (2014) memberikan sejumlah langkah yang dapat dilakukan dosen bahwa dalam melatih keterampilan berpikir pada mahasiswa harus selalu dihadapkan pada soal-soal berpikir tingkat tinggi dalam ranah pembelajaran. Sehingga dosen tidak hanya mengajarkan bahasa dan konsep tetapi juga memberi tahu pada mahasiswa tentang apa yang harus mereka lakukan dalam berpikir tingkat tinggi. Misalnya, siswa dapat mengenali keterampilan yang akan dilatihkan dengan tingkat kerumitan pertanyaan. Dimana 4C's meliputi: Critical Thinking, agar dapat melatih mahasiswa untuk memunculkan ide-ide atau pemikiran baru dalam menyelesaikan permasalahan tersebut, dan juga melatih mahasiswa agar dapat menyeleksi dan membedakan mana pendapat yang relevan dan tidak relevan, atau yang benar dan tidak benar. Hal ini sesuai dengan pendapat dari Zubaidah (2019), bahwa keterampilan berpikir kritis merupakan keterampilan dominan yang harus diajarkan secara eksplisit.. Melalui keterampilan berpikir kritis diharapkan mahasiswa mampu menggunakan sistem berpikir untuk membuat alasan yang efektif, memecahkan masalah, menghitung kemungkinan, membuat kesimpulan, dan membuat keputusan. Demikian juga dengan Creative Thinking, agar mahasiswa dapat menemukan dan menciptakan ide-ide kreatif dan baru dalam menyelesaikan suatu permaslahan. Dimana kreatifitas adalah cara-cara berpikir divergen, produktif, berdaya cipta berpikir heuristik dan berpikir lateral yang dapat diajarkan secara eksplisit dalam

338 BRILIANT: Jurnal Riset dan Konseptual Volume 6 Nomor 2, Mei 2021 
pembelajaran (Zubaidah, 2019). Beberapa cara yang dapat dilakukan untuk melatih berpikir kreatif pada mahasiswa, adalah a) memberikan permasalahan dan melibatkan mahasiswa agar berpartisipasi aktif dalam pembelajaran; b) mengeksplorasi topik dan materi dikaitkan dengan konteks nyata; c) menggunakan cara baru untuk menyelesaikan permaslahan (Coffman dalam Zubaidah, 2019).

Communicative, melatih mahasiswa agar dapat mengomunikasikan dan mempresentasikan hasil penyelesaian masalah dalam diskusi kelas. Oleh karena itu, keterampilan berkomunikasi harus dilatihkan sejak dini. Beberapa keterampilan komunikasi yang dikembangkan dalam pembelajaran. Menurut (Arsad \& Soh, 2011), antara lain: a) mampu menyampaikan informasi dan dapat dipahami oleh penerima informasi, b) mampu berkomunikasi secara lisan dan tulisan melalui media, c) mampu memilih media dan berkomunikasi dengan tepat, sehingga sesuai dengan karakter penerima pesan, d) mampu menggunakan teknologi atau digital lainnya dalam mengungkapkan ide dan pendapat. e) mampu berinteraksi secara kooperatif dan kolaboratif. Keterampilan berkomunikasi dengan baik membutuhkan waktu dan latihan, maka dapat dilatihkan secara terus menerus, baik secara eksplisit ataupun melalui proses pembelajaran dan bahan ajar. Keterampilan utama yang terkait dengan keterampilan komunikasi adalah mengubah informasi dan memecahkan masalah melalui bahasa. Selain itu, kemampuan mahasiswa dalam menilai, menganalisis dan mensintesis informasi melalui komunikasi menjadi hal yang penting.

Collaborative, melatih mahasiswa dapat bekerja sama dan saling toleransi dengan anggota yang lain dalam menyelesaikan permasalahan. Dengan adanya perkembangan teknologi dan era keterbukaan, memerlukan tenaga kerja abad 21 yang mampu melakukan kerja kolaboratif yang sering melibatkan anggota tim. Kolaborasi dalam pembelajaran merupakan suatu bentuk kerjasama antar mahasiswa saling membantu dan melengkapi untuk mengerjakan tugas-tugas tertentu agar mencapai tujuan yang ditentukan. Keterampilan kolaborasi yang dapat dikembangkan dalam pembelajaran, menurut Kivunja, C. (2014), antara lain: a) bertanggung jawab untuk bekerja sama dengan orang lain untuk menghasilkan tujuan tertentu, b) menghargai dan menghormati perbedaan pendapat, c) mampu bekerja efektif dan fleksibel dalam tim.

Pentingnya keterampilan 4C's bagi mahasiswa calon guru, karena tuntutan perkembangan Zaman. Karena keterampilan-keterampilan tersebut sangat dibutuhkan agar berhasil dalam hidup mereka setelah lulus kuliah. Kivunja (2014) menyebut pembelajaran dengan melibatkan keterampilan abad 21 ini sebagai paradigma pembelajaran baru. Namun keterampilan-keterampilan tersebut belum banyak dilibatkan dalam pembelajaran. Oleh karena itu dalam penelitian ini telah menunjukkan bahwa bahan ajar mata kuliah kalkulus I yang diintegrasikan dengan PPK, literasi, dan 4C's lebih efektif meningkatkan keterampilan berpikir tingkat tinggi mahasiswa dibandingkan dengan bahan ajar dari hand out dosen. Hal ini juga didukung oleh Kivunja (2014), bahwa keterampilan abad 21 ini merupakan keterampilan pembelajaran dan inovasi yang harus diajarkan secara efektif, karena diperlukan lulusan perguruan tinggi agar sukses di masa kini, dan dalam dunia digital. 


\section{KESIMPULAN}

Dalam penelitian ini pendekatan penelitian yang digunakan quasi eksperimental desain. Sebelum dilakukan uji hipotesis, dilakukan dulu uji data pretes menggunakan SPSS 23.0 for Windows, terlebih dahulu dilakukan uji pasyarat, yaitu uji normalitas untuk kelompok eksperimen diperoleh nilai sig $=$ 0,200 > 0,05, demikian juga pada kelompok kontrol diperoleh nilai sig=0,096 > 0,05. Maka data pretes kelompok eksperimen dan kelompok kontrol memenuhi distribusi normal. Demikian juga uji homogenitas menggunakan uji Levene's pada Kelas eksperimen dan kelas kontrol diperoleh nilai sig 0,780>0,05, maka kedua kelas memiliki varians yang sama atau homogen. Sedangkan uji kesamaan rata-rata dengan menggunakan uji t dua pihak dengan uji Independent Sample T-Test diperoleh nilai sig.2-tailed $=0,308>0,05$, maka $H_{0}$ diterima. Kesimpulan bahwa kelas eksperimen (menggunakan bahan ajar terintegrasi PPK, Literasi, 4C's) dan kelompok kontrol (menggunakan hand out dosen) tidak berbeda secara signifikan.

Sedangkan untuk mengetahui uji efektivitas dengan cara menganalisis data postes. Untuk melakukan uji hipotesis menggunakan SPSS 23.0 for Windows, terlebih dahulu dilakukan uji pasyarat, yaitu uji normalitas menggunakan uji Lilliefors (Kolmogorov-Smirnov) normality test untuk data postes diperoleh nilai sig. $=0,109$ pada kelompok eksperimen dan 0,152 kelompok kontrol lebih besar dari 0,05, maka dapat disimpulkan bahwa data potes kelompok eksperimen dan kelompok kontrol berdistribusi normal. Demikian juga uji homogenitas menggunakan uji Levene's pada Kelas eksperimen dan kelas kontrol memperoleh nilai sig. $=0,780$, lebih besar dari 0,05, maka dapat disimpulkan bahwa data kelompok eksperimen dan kelompok kontrol homogen. Sedangkan uji hipotesis dilakukan dengan menggunakan uji t dua pihak menggunakan Independent Sample $T$-Test dengan taraf signifikansi 0,05, diperoleh nilai sig.2-tailed $=0,018$ lebih kecil dari 0,05 , maka $H_{0}$ diolak. Ini menunjukkan bahwa kemampuan berpikir tingkat tinggi mahasiswa antara kelas eksperimen (menggunakan bahan ajar terintegrasi PPK, Literasi, 4C's) dan kelompok kontrol (menggunakan hand out dosen) berbeda secara signifikan.

Selanjutnya dilakukan uji hipotesis untuk mengetahui mana yang lebih efektif penggunaan bahan ajar kalkulus I teringrasi dengan PPK, literasi, dan 4C's dengan hand out kalkulus I dari dosen, maka dilakukan uji t satu pihak yang dihitung secara manual dengan taraf signifikansi 0,05. Hasil hitungan manual, diperoleh nilai $t_{\text {hitung }}=25,7557$ lebih besar dari $t_{\text {Tabel }}=1,672$, dengan $d k=$ 55, sehingga dapat disimpulkan kemampuan berpikir tingkat tinggi kelas eksperimen dengan bahan ajar terintegrasi PPK, literasi, dan 4C's lebih baik daripada kelas konvensional yang menggunakan hand out kalkulus I dari dosen.

\section{SARAN}

Peneliti merekomendasikan bagi dosen kalkulus I untuk menerapkan bahan ajar mata kuliah kalkulus I yang diintegrasikan dengan PPK, literasi, dan 4C's, karena lebih efektif meningkatkan keterampilan berpikir tingkat tinggi (kemampuan berpikir kritis dan berpikir kreatif) mahasiswa dibandingkan dengan hand out dosen. Diperlukan penelitian lebih lanjut dengan melibatkan sampel yang lebih luas.

340 BRILIANT: Jurnal Riset dan Konseptual Volume 6 Nomor 2, Mei 2021 


\section{UCAPAN TERIMA KASIH}

Ucapan terima kasih ditujukan kepada Kementerian Riset dan Teknologi/Badan Riset dan Inovasi Nasional, Nomor B/87/E3/RA.00/2020 sebagai penyedia dana dalam penelitian ini, dengan skim PTUPT Tahun 2020. Terima kasih juga kepada Rektor dan Ketua LPPM Unisma karena telah memberikan kesempatan kepada peneliti untuk melakukan penelitian. Penulis juga menyampaikan ucapan terima kasih Tim Redaksi Jurnal Briliant: Jurnal Riset dan Konseptual yang telah berkenan menerbitkan artikel ini.

\section{DAFTAR RUJUKAN}

Abdullah, M., \& Osman, K. 2010. Scientific inventive thinking skills among primary students in Brunei. Procedia-Social and Behavioral Sciences, 7, 294301.

AITSL 2011. Australian Professional Standards for Teachers. Education Council, PO Box 202, Carlton South, VIC 3053, Australia. Online: https://www.aitsl.edu.au/docs/default-source/national-policy-

framework/australian-professional-standards-for-teachers.pdf. Diakses 20 Oktober 2020.

Arsad, N. M., Osman, K., \& Soh, T. M. T. 2011. Instrument development for 21st century skills in Biology. Procedia-Social and Behavioral Sciences, 15, 1470-1474.

Collins,R. 2014. Skills for the 21st century: Teaching higher-order thinking. Curriculum and Leadership Journal. Online: http://www.curriculum.edu.au/leader/teaching_higher_order_thinking,37431 .html?issueID=12910. Diakses 20 Oktober 2020.

Conklin, W \& J. Manfro. 2012. Higher order thinking skills to develop 21st century learners. Shell Education Publishing, Inc. Huntington.

Depdiknas.2003. Undang-undang RI No.20 tahun 2003.tentang sistem pendidikan nasional.Jakarta

Depdiknas, 2006. Permen Nomor 22 Tahun 2006. Jakarta : Depdiknas

Griffin, P., \& Care, E. (2015). Assessment And Teaching of 21st Century Skills: Methods and Approach. Dodrecht:Springer Business Media.

Kemendikbud. 2017. Gerakan Literasi Sekolah. Direktorat Jenderal Pendidikan Dasar dan Menengah Kementerian Pendidikan dan Kebudayaan.

Kivunja,C. 2014. Innovative Pedagogies in Higher Education to Become Effective Teachers of 21st Century Skills: Unpacking the Learning and Innovations Skills Domain of the New Learning Paradigm. International Journal of Higher Education, 3(4), 37.

Limbach. B \& Waugh.W. 2009. Developing Higher Level Thinking. Journal of Instructional Pedagogies: Chadron State College.

NEA. 2012. Preparing 21st Century Students for a Global Society. Online: https://www.cacsd.org/cms/lib/NY01001870/Centricity/Domain/485/AGuide-to-Four-Cs.pdf. Diakses 20 Oktober 2020.

Nurdyansyah dan Fahyuni, Eni Fariyatul. 2016. Inovasi Model Pembelajaran.Nizamia Learning Center: Sidoarjo. 
Partnership for 21st Century Skills. 2009. Framework for 21st Century Learning. Available at : hhttps://www.teacherrambo.com/file.php/1/ Advances in Social Science, Education and Humanities Research, volume 477691 21st_century_skills.pdf (Accessed: April 4, 2020).

Partnership for 21st Century Skills. 2007. Framework for 21st Century Learning. Available at : http://static.battelleforkids.org/documents/p2 1/P21_framework_0816_2pgs.pdf (Accessed: April 4, 2020).

Peraturan Presiden RI, No. 87 Tahun 2017. Tentang Penguatan Pendidikan Karakter. Jakarta

Prihandoko, 2006, Pemahaman dan Penyajian Konsep Matematika secara benar dan menarik Jakarta : Dediknas

Setianingsih, Wita. 2018. LPTK dan Profesionalisme Calon Guru Abad 21. Makalah disampaikan Seminar Nasional IKA UNY Tahun 2018 "Profesionalisme Guru Abad XXI". Tersedia online: https://core.ac.uk/download/pdf/189575644.pdf, Diakses 28 Oktober 2020.

Setiawati; et al. 2018. Buku Penilaian Berorientasi Higher Order Thinking Skills. Jakarta: Direktorat Jenderal Guru dan Tenaga Kependidikan

Sugiyono. 2010. Metode Penelitian Pendidikan Pendekatan Kuantitatif, kualitatif, dan $R \& D$. Bandung: Alfabeta

Undang-udang RI. No 14 Tahun 2015. Tentang Guru dan Dosen

Trilling, Bernie and Fadel, Charles. 2009. 21st Century Skills: Learning for Life in Our Times, John Wiley \& Sons, 978-0-47- 055362-6.

Zubaidah, S. 2018. Mengenal 4C: Learning and Innovation Skills Untuk Menghadapi Era Revolusi IndustrI 4.0. Makalah Disampaikan pada Seminar "2nd Science Education National onference" di Universitas Trunojoyo. Online: file:///C:/Users/USER/Downloads/MAKALAHSENCO_UNIJOYOSitiZubaidah\%20(9).pdf. Diakses 20 Juli 2020. 